IZA DP No. 8324

Made in China, Sold in Norway:

Local Labor Market Effects of an Import Shock

Ragnhild Balsvik

Sissel Jensen

Kjell G. Salvanes

July 2014 


\title{
Made in China, Sold in Norway: Local Labor Market Effects of an Import Shock
}

\author{
Ragnhild Balsvik \\ Norwegian School of Economics \\ Sissel Jensen \\ Norwegian School of Economics \\ Kjell G. Salvanes \\ Norwegian School of Economics, IZA and CEEP
}

Discussion Paper No. 8324

July 2014

IZA

P.O. Box 7240

53072 Bonn

Germany

Phone: +49-228-3894-0

Fax: +49-228-3894-180

E-mail: iza@iza.org

\begin{abstract}
Any opinions expressed here are those of the author(s) and not those of IZA. Research published in this series may include views on policy, but the institute itself takes no institutional policy positions. The IZA research network is committed to the IZA Guiding Principles of Research Integrity.

The Institute for the Study of Labor (IZA) in Bonn is a local and virtual international research center and a place of communication between science, politics and business. IZA is an independent nonprofit organization supported by Deutsche Post Foundation. The center is associated with the University of Bonn and offers a stimulating research environment through its international network, workshops and conferences, data service, project support, research visits and doctoral program. IZA engages in (i) original and internationally competitive research in all fields of labor economics, (ii) development of policy concepts, and (iii) dissemination of research results and concepts to the interested public.
\end{abstract}

IZA Discussion Papers often represent preliminary work and are circulated to encourage discussion. Citation of such a paper should account for its provisional character. A revised version may be available directly from the author. 
IZA Discussion Paper No. 8324

July 2014

\section{ABSTRACT \\ Made in China, Sold in Norway: Local Labor Market Effects of an Import Shock}

We analyze whether regional labor markets are affected by expo- sure to import competition from China. We find negative employment effects for low-skilled workers, and observe that low-skilled workers tend to be pushed into unemployment or leave the labor force altogether. We find no evidence of wage effects. We partly expect this in a Nordic welfare state where firms are flexible at the employment margin, while centralized wage bargaining provides less flexibility at the wage margin. Our estimates suggest that import competition from China explains almost $10 \%$ of the reduction in the manufacturing employment share from 1996 to 2007 which is half of the effect found by Autor, Dorn and Hanson (2013) for the US.

JEL Classification: F16, H53, J23, J31

Keywords: import competition, local labor markets, Norway

Corresponding author:

Kjell G. Salvanes

Norwegian School of Economics

Helleveien 30

5045 Bergen

Norway

E-mail: kjell.salvanes@nhh.no

\footnotetext{
* We acknowledge the Norwegian Research Council for its financial support and thank participants at a conference on the Nordic model held in Oslo in September 2012 and two referees for their helpful comments and suggestions.
} 


\section{Introduction}

The rise of China as a major exporter in the world economy is an important feature of the current globalization process. Between 1993 and 2010, the share of world merchandize exports originating in China grew from $2.5 \%$ to 10.6\%, making China in 2010 the largest exporter in the world. Parallel to this increase in exports from low-cost countries, scholars have pointed out that imports from developing countries in general, and from China in particular, could have disruptive effects on labor markets in developed countries and, in particular, harm low-skilled workers in industries competing with imports from low-cost countries. However, until recently there has been limited evidence finding clear labor market effects of trade shocks (Krugman, 2008). The main conclusion from the earlier literature using data from the 1980s and early 1990s was that the rising wage inequality observed in many countries was mainly because of skill-biased technological change and not trade (Berman, Bound and Machin, 1998).11 As trade has increased between developed countries and low-cost countries, in particular China, following its inclusion in the World Trade Organization (WTO) in 2001, a number of recent studies have found labor market effects of trade shocks.

In this paper, we investigate how the increased exposure to imports from China has affected local labor market outcomes in Norway, using data for the period from 1996 to 2007. Our point of departure is the growing body of research examining the regional dimensions of trade shocks by taking into account the fact that regional differences in the production and employment structure within countries tend to make some regions more susceptible to trade shocks. Our empirical analysis is based on the approach of Autor et al. (2013), who investigate the impact of increased exposure to imports from China on various labor market outcomes in US commuting zones.

Autor et al. (2013) estimate that around $20 \%$ of the reduction in the employment share of manufacturing in the US from 1990 to 2007 resulted from the

\footnotetext{
${ }_{1}^{1}$ Salvanes and Førre (2004) reach a similar conclusion using data from Norway for the period 1986-94.
} 
increase in import competition from China during the period 2 The results in Autor et al. (2013) complement the industry-level analysis of Bernard, Jensen and Schott (2006), who find that US manufacturing plant survival and growth are negatively associated with industry-level exposure to import competition from low-wage countries. Several studies also use detailed data to study the wage effects arising from differences in exposure to various types of trade shocks 3

Like many other Organization for Economic Cooperation and Development (OECD) countries, Norway has experienced reductions in manufacturing employment together with increased imports from China. Figure 1 compares these developments in Norway and the US. As shown, in both countries imports from China have increased more than sixfold, while the manufacturing employment share has declined. However, despite the similarity of the developments depicted in Figure 1, the compositions of the manufacturing sectors in the US and Norway are rather different. For example, unlike the case in the US, Norwegian manufacturing is largely resource based, the economy is very open, with a large share of its production exported, and the R\&D intensity of the manufacturing sector is relatively low. We study the correlations between the relative sizes of industries within the Norwegian manufacturing sector and changes in China's export capacity in these differ-

\footnotetext{
${ }^{2}$ Seminal studies exploiting regional variations in exposure to trade shocks largely focus on trade shocks arising from changes in trade policy; see e.g. Topalova (2010), Chiquiar (2008), and Kovak (2013). For the most part, these studies employ a weighted average of trade policy changes across industries to create measures of regional variation in exposure to trade shocks. Kovak (2013) provides a theoretical foundation for the use of such measures based on a specific factors model of regional economies.

${ }^{3}$ For example, Verhoogen (2008) finds that in Mexico, within-industry wage inequality increased after a devaluation as the more-productive firms increased their exports, upgraded the quality of their export products, and increased their wages relative to lessproductive firms. Elsewhere, Amiti and Davis (2012) examine the effects of tariff cuts in Indonesia, and find that the wage effects for workers depend on both the type of tariffs being reduced and the export or import orientation of the firms, while Hummels, Jorgensen, Munch and Xiang (2014) consider firm-level offshoring in Denmark, and find both wage winners and losers within firms, depending on the skills and occupations of the workers. Finally, Ebenstein, Harrison, McMillan and Phillips (2011) analyze the effects of trade shocks at the occupation level in the US, and find that although the wage effects of import competition from low-wage countries within manufacturing are relatively small, there is a large negative effect for workers relocating from manufacturing to the service sector.
} 
ent industries, and we further compare these results for Norway with other OECD countries. Compared with the manufacturing structure of the US, for instance, Norway has a smaller employment share in some of the industries in which Chinese exports have increased the most from the mid-1990s (such as computers and clothing). At the same time, Norway has relatively large manufacturing employment shares in industries less exposed to competition from Chinese export growth (including food processing, pulp and paper, and shipbuilding and repairs). Yet other industries strongly exposed to Chinese exports (especially machinery and equipment and fabricated metal) are of similar relative sizes in both Norway and the US.

In addition to these differences in industry structure, labor market institutions differ markedly between the US and Norway. In general, Norway has the institutional characteristics of the so-called 'Nordic model'. One important feature of this model is a centralized wage bargaining system that has produced a relatively compressed wage structure that has not changed much over time (Aaberge, Bjorklund and Smith (2000), Hægeland, Klette and Salvanes (1999), and Kahn (1998)) ${ }^{4}$ At the same time, the rules for employment protection in Norway are relatively flexible when it comes to employment adjustment, with few limitations preventing firms from dismissing workers collectively when under stress. A further feature of the "Nordic model' is a welfare state that provides generous unemployment benefits and disability pensions. These policies provide workers with insurance from the negative income consequences of trade shocks. The limited wage flexibility arising from a system of centralized wage bargaining, combined with flexibility in employment adjustment and a generous welfare state, lead us to expect a clear impact of trade shocks on employment, but a more limited impact on earnings.

While the overall composition of the manufacturing sector in Norway in 1996 was such that employment shares were relatively small in several of the industries in which Chinese world exports have increased the most, the focus

\footnotetext{
${ }_{4}^{4}$ Moene and Wallerstein (1997) and Agell and Lommerud (1997) discuss various consequences of low wage inequality for growth and innovation.
} 
of our paper is to assess the local labor market consequences of increased exposure to imports from China. For this analysis, we follow the approach of Autor et al. (2013) (hereafter ADH) and exploit the fact that different regional labor markets are specialized in different manufacturing industries, and as a consequence, they experience different impacts from import competition from China. For example, the Chinese export supply shock may affect a labor market region in Norway by generating increased competition in those markets where the producers of that region sell their products. We consider both the direct competition from China through imports to Norway and the change in competition that Norwegian labor market regions may face in their export markets. At the same time, falling trade costs and economic growth in China may increase Chinese demand for a region's products, and thus we also need to take into account the increase in exports to China from Norway. We analyze first how the trade shock affects the manufacturing employment share, and then how the shock in turn affects employment in other sectors, regional labor market mobility, unemployment, and wages.

In terms of results, we find a negative impact of exposure to competition from China on the manufacturing employment share in Norwegian local labor markets. This negative effect on the manufacturing employment share is related to imports of intermediate products, rather than imports of products for final consumption. Further, the effect is primarily because of the exposure to imports from China to Norway, and not competition from China in Norwegian export markets. We find that an increase in regional exposure to imports from China of 10,000 Norwegian kroner (NOK) per worker results in a decline in the manufacturing employment share of the working-age population of 0.125 percentage points. As a point of comparison, ADH find for the US that an increase in exposure to imports from China of 1,000 US dollars (USD) (equal to approximately 7,000 NOK) results in a decline in the manufacturing employment share of about 0.6 percentage points. Donoso, Martín and Minondo (2014) also identify large negative effects in their analysis of regional labor markets in Spain, finding that a 1,000 USD increase in imports from China per worker reduces the share of manufacturing em- 
ployment in the working-age population by 1.3 percentage points. This is about twice the impact identified by ADH for the US. Dauth, Findeisen and Suedekum (2014) undertake a similar exercise for Germany, and find that increased exposure to imports from China reduces the manufacturing employment share in German local labor markets by about 0.14 percentage points, although Germany's improved export opportunities thanks to the rise of China compensate for this negative effect. We do not find that this is the case for Norway. Further, we find that unskilled workers, who to some extent are pushed into unemployment or out of the labor force altogether, bear the brunt of the reduction in manufacturing employment caused by the Chinese import shock. However, as opposed to the US case, we do not find negative wage effects. These latter results are to be expected in a Nordic welfare state where wage flexibility is low, and thus where we instead expect the margin of adjustment to be on employment.

The remainder of the paper is structured as follows. Section 2 provides a brief comparison of several different countries and their exposures to the increase in Chinese export capacity. We also discuss the development of Norwegian imports from China. Section 3 presents our empirical strategy. We provide a brief description of our data sources in Section 4 , along with descriptive statistics for our measures of regional exposure to competition from China, and we document the regional differences in manufacturing employment structure. Section 5 presents our estimation results and Section 6 concludes.

\section{Chinese export capacity and the industry structure of importing countries}

The increase in Chinese exports has not been uniform across industries and products. Textiles, office machinery and computers, and radio, TV, and communication equipment are the industries with the largest increase in ex- 
port value from 1996 to $20075^{5}$ Countries that in 1996 had a large share of manufacturing employment in industries that experienced subsequent large increases in Chinese export capacity are likely to be more exposed to competition from China. We compare different countries' exposures to competition from China by computing the within-country correlation coefficient between the manufacturing employment share in each of 20 industries and the change in the value of Chinese exports of products from that industry. Figure 2 plots the resulting correlation coefficients for OECD countries, where Norway appears to be the least-exposed country according to this measure 6 . In evidence, Norway has a correlation coefficient of just -0.284 , whereas the corresponding value for the US is 0.154 (much closer to the OECD average of 0.167$)$.

In Figure 3, we plot the employment shares that provide the basis for the correlation coefficients for Norway and the US in Figure 2 against the increases in worldwide Chinese exports from these industries. This figure includes only those industries that in 1996 accounted for $5 \%$ or more of manufacturing employment in at least one country, or industries where the total export value from China increased by 100 billion USD or more from 1996 to 2007. As shown, the three industries with the largest employment shares in Norwegian manufacturing, namely, food products, pulp and paper, and the building and repair of ships, accounted for almost $50 \%$ of manufacturing employment in 1996. These industries experienced relatively small increases in Chinese exports, and they accounted for a larger share of manufacturing employment in Norway than in the US (about 50\% versus 25\%). The situation is almost the opposite for the three industries that experienced the largest increase in Chinese exports, namely, textiles, office machinery and computers, and radio, TV, and communication equipment. Each of these industries accounted for a larger share of manufacturing employment in the US than in Norway

\footnotetext{
${ }^{5}$ We can see this from the horizontal axis in Figure 3 , where the export data are from the OECD STAN bilateral trade database.

${ }^{6}$ Country data for each industry's employment share (i.e. percentage of the total employment in manufacturing) are from the OECD STAN indicators database, while the data for total exports from China across the 20 different industries are from the OECD STAN bilateral trade database
} 
in 1996. The machinery and equipment industry is also relatively large in Norway, comparable to the relative size of this industry in the US, and it also faced large increases in Chinese exports over this period.

Figure 4 depicts Norwegian imports from China. Largely, the Norwegian import pattern is in line with the change in total world exports from China. The left-hand panel of Figure 4 shows the percentage growth in imports of products from different two-digit General Industrial Classification of Economic Activities within the European Communities (NACE) industries, while the right-hand panel shows the value of imports in 2007 for these same industries. As shown, while the growth in imports of computers and electronic equipment has been particularly significant since 1996, clothing remains the largest broad category of imports from China in 2007 in terms of value. The three industries that experienced the greatest growth in Norwegian imports are among the four industries that experienced the largest increase in Chinese export capacity, as shown in Figure 3. Overall, in Norway, the total import share from low-wage countries increased from 7\% in 1996 to $13 \%$ in 2007, with most of this increase coming from China. Similarly, the share of imports from developing countries accounted for by China increased from about $30 \%$ in 1996 to $50 \%$ in 2007.

On one hand, the composition of Norwegian manufacturing in 1996 was such that the subsequent rise of China is likely to have generated less competitive pressure on manufacturing production than in many other OECD countries. One reason is that Norway is largely a resource-based economy. Natural resources are abundant in the form of oil and gas, minerals, fish and aquaculture, forestry, and waterfalls, and a large share of Norwegian exports rely on transforming raw materials to other products through energy-intensive production processes. The rise of China has contributed to increasing the demand for many of the raw materials Norway exports. On the other hand, the R\&D intensity of Norwegian manufacturing is low relative to the OECD average. In evidence, according to Eurostat, R\&D expenditure in the private sector in Norway in 2009 was some $0.95 \%$ of GDP, while the OECD average was $1.25 \%$ and that for the most R\&D-intensive European Union (EU) 
countries was $2 \%$. Such low R\&D intensity could contribute to making Norwegian industries more vulnerable to competition from China than similar industries with higher R\&D intensities in other OECD countries.7

\section{Empirical approach}

Even if some of the industries that experienced the largest increases in Chinese export capacity shown in Figure 3 are relatively small at the national level in Norway, regional differences in manufacturing employment structure will mean that some labor market regions are more exposed to competition from imports from China than are other regions. Hence, the empirical analysis moves from the national perspective to the perspective of regional labor markets in Norway. We base our empirical approach on the theoretical and empirical framework developed in $\mathrm{ADH}$.

The main emphasis in ADH is to provide a framework for representing the Chinese supply shock as one that affects the demand for products manufactured by each regional labor market $]^{8}$ The Chinese supply shock can be seen as arising from a combination of the reduced trade costs China faced after accession to the WTO in 2001 and the increase in both productivity and production capacity following economic reforms in China since the late 1980s. This Chinese export supply shock may affect a given labor market region in Norway by generating increased competition in those markets where the producers of that region sell their products. At the same time, falling trade costs and economic growth in China may increase Chinese demand for the

\footnotetext{
${ }^{7}$ See, for instance, Bloom, Draca and Reenen (2011), who find that competition from China in OECD countries has led to the reallocation of labor toward more innovative and technologically advanced firms that are better able to survive the competition from low-cost countries.

${ }^{8}$ Their theoretical model is based on a trade model with monopolistic competition (Helpman and Krugman, 1985) where each labor market region is treated as a small open economy producing both differentiated traded goods and a homogeneous nontraded good. Industry labor productivity may differ between regions. Trade is assumed to have a 'gravity' structure (Arkolakis, Costinot and Rodriguez-Clare, 2012), which implies that the model maps changes in trade quantities onto labor market outcomes.
} 
region's products.

Consider the effect of the Chinese supply shock on employment in the Norwegian manufacturing sector. The increase in Norwegian imports from China of products from industry $i$ affects labor demand only in those regions where industry $i$ is located. Thus, we allocate the increase in imports of industry $i$ 's products over a period $t$ to region $r$ according to the region's share of total national employment in industry $i$ at the beginning of the period. We then take the sum of the import changes over all industries to arrive at a measure for each region that accounts for the increase in exposure to domestic imports from China. We then scale the total increase in import value by the total employment in region $r$ at the beginning of period $t\left(L_{r t}\right)$, yielding a measure of the increase in imports per worker as follows, which we designate as domestic exposure to China:

$$
\Delta D E C_{r t}=\frac{1}{L_{r t}} \sum_{i} \frac{L_{r i t}}{L_{i t}} \Delta M_{i t}
$$

According to the measure in (1), a region whose employment structure at the beginning of period $t$ is dominated by industries in which imports from China increase very little during the period will produce a low value of the measure calculated in (1). By contrast, regions that at the beginning of period $t$ have a large share of domestic output in industries in which Chinese imports increase substantially are more exposed to competition from China.

Competition from Chinese products in their export markets may also affect domestic producers. As an example, this could occur if an aluminum producer located in region $r$ has a large market share in Germany at the beginning of period $t$, and if Germany during period $t$ substantially increases its imports of aluminum from China. The magnitude of the increase in exposure to competition from China then depends on both the initial market share of region $r$ and the increase in imports of aluminum from China to Germany during period $t$. For each region, summing over all industries and all export markets, we arrive at our measure of the region's export market 
exposure to China:

$$
\Delta E E C_{r t}=\frac{1}{L_{r t}} \sum_{i}\left(\sum_{k} M S_{k i r t} \Delta M_{k i t}\right)
$$

In equation (2), $M S_{k i r t}$ is the initial 'market share' of region $r$ in country $k$ for products from industry $i$. The term $\Delta M_{k i t}$ captures the change in imports from China to market $k$ of products from industry $i$.

The premise of the measure of competition in equation (2) is that a labor market region $r$ with a large market share in Germany, for instance, in 1996 will be more exposed to competition from China if Germany subsequently increases its imports from China of the products exported to Germany by region $r$ in 1996. We calculate this market share by dividing the region's exports of the products of industry $i$ at the beginning of period $t$ by total domestic expenditure in market $k$ on the products of industry $i$. In order to arrive at an imputed measure of domestic expenditure in country $k$, we employ the following steps. First, we assume that the domestic expenditure shares for each industry are the same in all countries. We use the Norwegian input-output tables for 1996 and 2002 to calculate these expenditure shares. We then use information on total household and government consumption and gross capital formation from the World Bank indicators to arrive at total domestic consumption at the beginning of the period 9 We then multiply total domestic expenditure by the industry expenditure share to arrive at domestic expenditure by industry for Norwegian export markets in 1996 and in 200210

While competition from China in both their domestic and export markets may affect domestic producers, some producers may also potentially benefit

\footnotetext{
${ }^{9}$ The World Bank indicators do not contain information on the total use of intermediates, only on the end use by governments and households and on gross capital formation. We impute the total use of intermediates by assuming that the share of total domestic expenditure that is accounted for by intermediates in each industry is the same as what we find from the Norwegian input-output tables.

${ }^{10}$ To capture Norwegian export markets, we employ the same 17 OECD countries that we use in our instrument for imports from China. We have also expanded the set of export markets to all countries for which we could find data, but this does not affect our results.
} 
from the new market opportunities caused by the rise of China. We allocate the increase in Norwegian exports to China of the products of industry $i$ to regions according to each region's share of the national employment in industry $i$ at the beginning of the period. The change in exports per worker from each region to China is then:

$$
\Delta X_{r t}=\frac{1}{L_{r t}} \sum_{i} \frac{L_{r i t}}{L_{i t}} \Delta X_{i t}
$$

We can then calculate the net change in the exposure to competition from China as the sum of the measures in equations (1) and (2) minus the measure in equation (3).

The main purpose of our analysis is to investigate the extent to which the change in exposure to competition from China affected manufacturing employment in the regional labor markets of Norway. Our main regressions are variants of the following equation:

$$
\Delta M f S_{r t}=\beta_{1} \Delta C N \text { exposure }{ }_{r t}+\gamma_{t}+\gamma_{R}+X_{r t}^{\prime} \beta_{2}+\epsilon_{r t},
$$

where $\Delta M f S_{r t}$ is the change in the region's share of the working-age population employed in manufacturing, measured as the percentage point change from the start to the end of period $t . \Delta C N$ exposure $_{r t}$ represents measures of change in exposure to competition from China. Our main measure of exposure to competition from China is given in equation (1). As alternative measures of exposure to competition from China, we also use the sum of domestic and export market exposure in equations (1) and (2), and the sum of domestic and export market exposure net of exports to China, i.e. (1) $+(2)-(3)$.

Our data cover the period 1996-2007, and our main specifications split this period into two shorter periods: 1996-2001 and 2002-2007. Thus, we include a period dummy $\gamma_{t}$ when estimating equation (4) in first differences. The vector $\gamma_{R}$ contains five dummies for the different parts of Norway. Given that our regressions are in first differences, these dummies correspond to controlling 
for region-specific trends in the development of manufacturing employment. The vector $X_{r t}$ contains the start-of-period share of the population employed in manufacturing. This is a proxy for the role of manufacturing in the region and should ensure that our variables for import exposure to China do not pick up the general trend of a decline in the role of manufacturing - a trend that is likely to be stronger in regions more dependent on manufacturing. We also include a variable for the share of the regional population with a college education.

As unobserved demand and supply shocks at the regional level could simultaneously affect both the exposure to competition from China and regional economic performance, the trade exposure measure in equation (1) is potentially endogenous. However, the components of the measure in equation (2) are arguably determined independently of Norwegian trade and labor market shocks, and thus we are not overly concerned with the endogeneity of the exposure to competition from China in Norwegian export markets. In order to address the potential endogeneity of the measure in equation (1) and identify the causal impact of the Chinese supply shock, we follow the instrumental variable strategy in $\mathrm{ADH}$. This strategy rests on the assumption that the Chinese supply shock has created similar bundles of exports from China to most developed countries, and that the increase in imports from China in other developed countries is uncorrelated with labor demand shocks in Norwegian labor market regions. Thus, we create an instrument for domestic exposure to China in equation (1) by replacing the change in Norwegian imports from China in equation (1) with the change in imports from China to 17 other OECD countries ${ }^{11}$ As argued by ADH, if expected future increases in imports from China affect industry employment, then simultaneity bias could also affect our instrument. To address this concern, we lag the output shares used in the instrument by using output shares three

\footnotetext{
${ }^{11}$ The countries we use in the instrument are Australia, Belgium, Canada, Denmark, Finland, France, Germany, Italy, Ireland, the Netherlands, New Zealand, Portugal, Spain, Sweden, Switzerland, Great Britain, and the US. We have experiment by limiting the number of countries included in our instrument by dropping Australia, New Zealand, and Portugal. This does not affect our results.
} 
years prior to the beginning of the period ${ }^{12}$

A further issue likely to be of some importance in a small open economy, such as Norway, is the role of exports. During the period from 1996 to 2007, Norway increased its nonoil exports substantially. As increases in exports to destinations other than China could counteract the effect of import competition from China on employment, we add a control variable capturing the total change in regional exports per worker (excluding exports to China).This control variable could also be endogenous, but our main results are unchanged if we do not include this control variable.

\section{Data and descriptive statistics}

\subsection{Data sources}

We draw on a combination of data sources for our analysis. First, we use the Norwegian customs data from Statistics Norway to identify imports from China. The customs data are at a very detailed product level, but we aggregate imports into the product categories produced by each NACE four-digit industry. In order to aggregate the detailed product codes in the customs data into outputs at the four-digit industry level, we use the correspondence table produced by Statistics Norway mapping between the commodity codes at the Harmonized System (HS) eight-digit level and the Statistical Classification of Products by Activity in the European Economic Community (CPA) codes at the six-digit level. The CPA codes at the four-digit level correspond to the four-digit codes in the NACE.

Next, we calculate both import and export measures at the four-digit indus-

\footnotetext{
${ }^{12}$ The starting year for our analysis, 1996, corresponds to a change in the industry classification system in Norway from the International Standard Industrial Classification (ISIC) to NACE. A correspondence going backward would imply an unfortunate increase in the level of industry aggregation. To avoid this, we calculate the output shares in 1993 using only the plants from 1996 that were also in operation in 1993 and assuming they had the same NACE four-digit industry classification as in 1996.
} 
try level for each of 160 labor market regions in Norway, and then weight them using the regional employment shares in each four-digit industry, as calculated from the Norwegian employer-employee data. The Norwegian employer-employee data contain information on the entire population between 16 and 74 years of age and the identity of the employers of those who work. For each four-digit industry, we calculate the total national employment as the number of people employed by firms in this industry, and the industry employment share of each region as the share of national employment in firms located in the region. The Norwegian employer-employee data are also used to calculate our start-of-period control variables in equation (4). From this source, we have information about education and can calculate the share of the working-age population (aged between 16 and 67 years) with a college education. From the employer ID in this data source, we can also calculate the manufacturing employment share in the region, which is required for both the start-of-period control variable and our dependent variable in equation (4).

We divide Norway into labor market regions using the classification developed in Gundersen and Jukvam (2013). This division uses information about commuting patterns. Data on the international trade of countries other than Norway are from the United Nations Commodity Trade Statistics Database (Comtrade). We use the HS commodity classification at the six-digit level, and harmonize the different HS classifications over time using the concordance developed by Beveren, Bernard and Vandenbussche (2012). We then aggregate these commodity codes into the four-digit NACE industry classifications using the same HS-to-CPA correspondence we used for the Norwegian customs data. Finally, we convert all dollar values in the Comtrade database and the World Bank development indicators to NOK using the average annual exchange rates available on the Norwegian Central Bank's Web page ${ }^{13}$

\footnotetext{
${ }^{13}$ http://www.norges-bank.no/
} 


\subsection{Exposure to China of Norwegian labor markets}

The measure of exposure to domestic import competition in (1) makes it clear that the sources of regional variation in import exposure are the regional differences in the shares of employment in manufacturing and the specialization of manufacturing employment in import-intensive industries. Analyzing the regional differences will also clarify where the Norwegian economy encounters competition from China. As a starting point, a simple decomposition of variance indicates that while there are differences in the manufacturing employment shares across regional labor markets, the start-of-period manufacturing employment share explains only about $12 \%$ of the variation in the change in exposure to imports from China, suggesting that regional specialization is the more important factor in determining the import exposure of different regions.

Table 1 details the Norwegian labor market regions with the smallest and largest manufacturing employment shares in 1996, and the regions with the highest and lowest percentage point changes in these shares from 1996 to 2007.14 Among the top six regions according to manufacturing employment share in 1996, smelter plants, making use of hydroelectric power to produce metals, dominate four. The two remaining regions in the top six are Stranda, which is one of the centers for the Norwegian furniture industry and also has a large food-processing plant, and Båtsfjord, which is a small community in the north of Norway with several fish-processing plants.

On average, there has been a decline of almost 2 percentage points in manufacturing shares over the period from 1996 to 2007. Only a few regions have experienced an increase in manufacturing shares - nearly always regions with very small populations. Of the six regions with the largest decreases in manufacturing employment shares, the top five are dominated by processing industries related to fisheries.

There are also large differences in the exposure to imports from China. Even

\footnotetext{
${ }^{14}$ We have titled the regions with the name of the municipality with the largest population within the region, if the region contains more than one municipality.
} 
the median region has a calculated exposure of only 4,000 NOK per worker, while the region at the 75 th percentile experienced an increase in import exposure of 12,000 NOK over the 11-year period. At the 90th percentile, this increase is 27,000 NOK 15 Figure 5 illustrates the regional variation in our calculated measure of change in exposure to domestic import competition from China separately for intermediate products and final goods. In comparing the maps in 5(a) and 5(b), we can see that some regions were primarily affected by imports of intermediate goods, while others were more affected by imports of final goods. The regions shaded darkly had an increase in exposure of more than 20,000 NOK per worker. For intermediate goods, this occurs in six of our 160 regions, while for final goods this is the case in 13 of the regions. Table 2 lists the most- and least-exposed regions for each of the two measures in Figure 5. The regions most exposed to competition from intermediate goods generally have a relatively diverse industry structure, with the possible exception of Bremanger, where a large smelter plant dominates employment. In addition, the six regions most exposed to competition from imported final goods are all relatively small in terms of population, and several have firms in the textile and furniture industries.

Table 3 provides summary statistics for the different measures of exposure to the Chinese supply shocks in equations (1)-(3). The exposure to competition from China in export markets, shown in the second row of Table 3 , is of lower magnitude than the direct competition from imports to Norway. ${ }^{16}$ For some regions, the new markets in China are more important than the increase in imports from China, as the net import exposure measure in the second-last

\footnotetext{
${ }^{15}$ Comparing these numbers with the calculations made by ADH for the US, the increase in import exposure to China for Norwegian labor market regions is somewhat smaller than for regions in the US. For instance, ADH report that the commuting zone at the median experienced an increase in exposure to total imports from China per worker of 2,100 USD (roughly 12,000 NOK) in 2000-07. This is about three times larger than the increase in exposure for the median region in our data set. For the region at the 90th percentile, the increase in exposure to China is about the same in Norway and the US.

${ }^{16}$ The population-weighted average exposure to competition from China increases by $45 \%$ when including the exposure to competition from China in Norwegian export markets. This is higher than what ADH find for the US, which is to be expected, given the greater export orientation of the Norwegian economy.
} 
row of Table 3 is negative. The bottom row of Table 3 shows the change in total exports per worker (excluding exports to China). Figure6 illustrates the regional variation in our calculated measure of change in exports to China and the change in total exports from each region in 1996-2007. In both cases, the regions shaded most darkly are the 13 regions that experienced the largest increases in exports per worker. Among the 13 regions with the largest increase in exports to China per worker, 10 are small coastal communities where fisheries and fish-processing activities prevail. One way to think about this is that the fish-processing industry in these communities benefits greatly from the increase in access to the Chinese consumer market. However, the reality is more likely the opposite, as a large proportion of the increased exports of fish to China are subsequently processed in China and then reexported back to the European market. This has reduced employment in fish processing, and four of the six regions with the largest reductions in manufacturing shares in Table 1 are among the leading regions in terms of the change in exports to China per worker. In these cases, it is not import competition from China that affects employment but rather a clear case of job offshoring 17

Turning to the distribution of our calculated measure of change in total exports (excluding exports to China) per worker, we can see that the distribution is highly skewed, as evident from the last row of Table 3 and the regional pattern shown in Figure 6(b). The seven regions with the largest calculated increases in exports per worker are all communities situated at the end of a fjord, close to a waterfall, and with a large smelter plant producing metal using hydroelectric power.

\footnotetext{
${ }^{17}$ In some of our regressions, we drop the 10 fishing communities with the largest calculated increases in exports to China per worker. Our results are robust with respect to this change.
} 


\section{Results}

We start by estimating the OLS relationship in equation (4) between the change in a region's manufacturing employment share and the change in its exposure to imports from China according to the measure defined in equation (1). Table 4 reports the results from the OLS regressions on the first differences for each of the 160 regions. In all of the regressions, we weight our observations by the initial population size, and the standard errors are clustered at the county level (yielding 20 clusters). Columns 1-3 of Table 4 exhibit evidence of a negative correlation between manufacturing employment shares and increased exposure to imports from China. However, the correlation in Column 1 does not consider other changes at the regional level that may be correlated with both changes in imports and the manufacturing employment share. Thus, in Columns 2 and 3 of Table 4 , we add controls that we hypothesize will reflect these other changes, including dummy variables for the second period, the share of the population with a college education, and the increase in total exports from the region. 18 We also include five regional dummies to control for region-specific trends affecting the manufacturing employment share, e.g. differences in the importance of the oil industry, internal changes in the demand for Norwegian-produced goods, or particular regional changes in the composition of the workforce. Adding these controls does not affect the coefficient for total imports.

Importantly, the measure of import exposure in equation (1) does not distinguish between imports of final and intermediate goods. Although an increase in imports will contribute to increasing the measure of exposure to imports from China as measured by (1), the impacts on employment may well differ between final and intermediate goods. For instance, while imports of final goods will be in direct competition with the products of region $r$, some part of the increase in imports of intermediates may be used as intermediate inputs by manufacturing firms located in the region. Consequently, imports

\footnotetext{
${ }^{18}$ The variable capturing the change in total exports from each region is potentially endogenous. None of our results on the effect of the change in import exposure is affected by whether we use this variable as a control.
} 
could lower the costs of local manufacturing and make the industry more competitive, and hence potentially increase labor demand. However, it is important to note that imports of these two types of goods may have similar effects on local labor markets. The important distinction is then whether the imports are in direct competition with the outputs of Norwegian manufacturing firms, or whether the imports are themselves inputs into Norwegian products. Clearly, many manufacturing firms have intermediate inputs as their main products, and thus imports of intermediate inputs could be in direct competition with the commodities produced by these Norwegian manufacturing firms. To reflect this, and as shown in Columns 4-6 of Table 4 , we split the import exposure measure in (1) into a part that accounts for the change in the import of final goods and another part that accounts for the change in the import of intermediate goods 19 The results suggest that the import of intermediate goods mainly drives the negative coefficient for total import exposure in Columns 1-3. This can be explained by the fact that many of the large manufacturing industries in Norway have as their main outputs intermediate goods to be used in other industries. ${ }^{20}$ As the classification of products into intermediate and final goods relies on less-than-perfect correspondence tables that leave some classifications open to question, we combine these two types of products into a single measure of total imports in the remaining analysis.

As argued in Section 3, actual imports to Norway may be endogenous and correlated with unobserved labor demand shocks. To address this problem, we develop an instrument to capture the change in imports to Norway using instead the change in imports from China to other wealthy OECD countries. Figure 7(a) plots the OLS reduced-form regression of the change in the manufacturing employment share on the instrument. As the figure shows, there is a significant negative relationship between the change in exposure to im-

\footnotetext{
${ }^{19}$ We allocate each six-digit HS code to either a final good or an intermediate input using the correspondence tables for the HS and the Broad Economic Categories (BEC) codes from Eurostat (http://ec.europa.eu/eurostat/ramon/). We classify capital goods as intermediate inputs.

${ }^{20}$ This would be the case for most major industries in Norway, with the exception of the food-processing industry.
} 
ports from China and the manufacturing employment share in a region. The first stage, shown in Figure 7(b), confirms that the increase in Norwegian imports from China is positively correlated with the change in imports from China for the countries we use in our instrument. Our first-stage results are shown in the appendix in Table A.1, and we see that the instrument is a good predictor of Norwegian imports.21

Table 5 presents our instrumental variable (IV) results. The reported coefficient in the first column of Panel A is the IV coefficient for the change in total domestic imports from China. As shown, the estimated coefficient does not change much from the analogous OLS estimates in Column 3 of Table 4. In Columns 2-4 of Table 5, we report the results for different measures of regional exposure to increased competition from China. In Column 2, we use the change in net imports from China, by subtracting our measure of regional exports to China from our measure of imports from China. In addition to import competition, we argued in Section 3 that competition from Chinese products may also affect Norwegian local labor markets via their export markets. Column 3 of Table 5 reports the estimated combined effect from these two sources of exposure to increased imports from China ${ }^{22}$ Finally, in Column 4, we subtract exports to China from the measure used in Column 3. As shown, the four estimated coefficients reported across Panel A of Table 5 are relatively similar, and the negative effect of increased exposure to competition from China appears to arise mainly from the increase in domestic imports.

As discussed in Section 4.2, of those regions that experienced the largest increases in exports to China, we identify 10 small coastal communities where fish processing is the dominant manufacturing activity. To an increasing extent, the Norwegian fishing industry ships minimally processed fish to China (and some other Asian countries) for filleting and packaging, before the pro-

\footnotetext{
${ }^{21}$ See Footnote 10 for the countries included in the instrument.

${ }^{22} \mathrm{We}$ also entered the exposure measures defined in equations (1) and (2) separately in the regression. However, the estimated coefficients for exposure in export markets were very small in magnitude, and not significantly different from zero, while the estimated coefficient for exposure to domestic imports from China was negative and significant.
} 
cessed products are re-exported from China to Europe. This has led to a large contraction of the fish-processing industry in many communities where this used to be the main source of employment. At the same time, these regions have less exposure to imports from China. However, these regions account for less than $1 \%$ of the population and are therefore given a very low weight in the regressions. In Panel B of Table 5, we repeat the IV regressions in Panel A after removing these 10 regions and confirm that the results in Panel A are more or less unaffected.

In Panel $\mathrm{C}$ of Table 5, we drop an additional three labor market regionsthose that experienced the largest population growth over the period of analysis, namely, Oslo, Trondheim, and Stavanger. The main reason for doing this is that these regions have large corresponding weights in our regressions and have experienced population growth that is part of a strong trend toward urbanization in Norway. In addition, migrants to Norway tend to settle in the larger cities, particularly Oslo. The large population growth in these regions will necessarily lead to a reduction in the manufacturing employment share, even if no manufacturing jobs are lost, and thus including these regions in our regressions may lead to overestimation of the negative effect of import exposure on manufacturing employment. Following this sampling change, Panel $\mathrm{C}$ of Table 5 shows that we obtain slightly smaller estimates of the exposure to import competition from China in all of the specifications. Hence, hereafter we base our estimates on the sample used in Panel C.

Our preferred specification in the bottom row of Column 1 in Table 5 is repeated in Column 1 of Table 6. Column 2 confirms the result of Column 1 for the difference for the whole period, while Columns 3 and 4 show the result for each period of the stacked first differences of Column 1 . The results indicate that the negative effect of import competition is particularly pronounced in the second period, following China's accession to the WTO. This is also the period that saw particularly steep growth in imports from China to Norway.

To assess the economic significance of our results, we can compare the es- 
timated trade-induced reduction in manufacturing employment shares with the decrease observed over the period 1996-2007. As stated by ADH, such an exercise assumes that trade with China affects the absolute level of manufacturing employment in Norway and not only relative manufacturing employment across labor markets. Our preferred specification is Column 1 in Table 6, which implies that a 10,000 NOK increase in exposure to total imports from China reduces the manufacturing employment share by 0.125 percentage points. Chinese import exposure rose by 2,700 NOK per worker between 1996 and 2001 and by an additional 10,100 NOK per worker in the six-year period between 2001 and 2007. Hence, using the estimated coefficient, the increased exposure to Chinese imports reduced manufacturing employment as a proportion of the working-age population by 0.03 percentage points in the first five-year period, and then by an additional 0.13 percentage points in the following six-year period.

At the same time, the manufacturing employment share of the working-age population fell by 0.78 percentage points between 1996 and 2001 and by 0.75 percentage points between 2002 and 2007. Thus, according to these calculations, the increased exposure to Chinese import competition explains only $4 \%$ of the manufacturing employment decline in the first period, $17 \%$ of the decline in the second period, and $10,5 \%$ of the decline in the entire sample period 23 ADH's comparable estimate for the US is that $44 \%$ of the US decline in manufacturing over the period from 1990 to 2007 can be explained by increased imports from China.

We use the actual increase in imports from China when calculating that increased imports from China account for about $10 \%$ of the reduction in manufacturing employment shares in Norway during the period from 19962007. The increase in imports from China to Norway has come about due to a combination of supply and demand forces. Thus, if the employment effect of demand-driven increases in imports are less negative than supply-driven increases, this may overestimate the causal effect of the Chinese supply shock

\footnotetext{
${ }^{23}$ The mean changes in import exposure and employment shares referred to here are weighted by the population in 1996 for the first period and 2001 for the second.
} 
on Norwegian manufacturing employment. ADH discuss how to isolate the variation in the import exposure measure that is driven by supply shocks by using the relationship between the OLS and 2SLS estimates. For the US case they then estimate that about half of the variation in the increase in imports from China to the US is driven by the exogenous supply shock, and thus they more conservatively conclude that $21 \%$ of the US decline in manufacturing over the full period from 1990 to 2007 can be explained by increased imports from China. Following their suggestion, we find that most of the decline in Norwegian manufacturing share found above is explained by the supply-driven increase in imports from China to Norway. According to our data, $91 \%$ of the variation in the increase in imports from China to Norway is driven by the exogenous supply shock, thus $9,5 \%$ of the decline in the Norwegian manufacturing share over the period from 1996 to 2007 can be explained by increased imports from China. This measured economic effect is about half the size of the effect for the US as found by $\mathrm{ADH}{ }^{24}$

\subsection{Other outcomes}

The next empirical question we address is how the negative effect of import exposure on manufacturing employment in turn affected labor mobility between regions and industries and other labor market outcomes, such as wages and unemployment. Table 7 presents the results for regional mobility, which help us assess whether greater exposure to imports from China caused workers to move out of some regions and into other, less-exposed regions. We identify no significant mobility effect of the increased exposure to imports from China. The first column of Table 7 reports the effect on the total working-age population, while Columns 2 and 3 report the effects on the working-age populations with and without a college education.

In Table 8, the five columns have as their dependent variable the log point

\footnotetext{
${ }^{24}$ Our estimated effects using the OLS and IV specifications are relatively similar, while $\mathrm{ADH}$ find for the US that the IV coefficient is much larger than the OLS coefficient. Thus, it makes sense that we find that almost all of the of the variation in the increase in imports from China to Norway is driven by the exogenous supply shock.
} 
change in the number of people in each of five labor market statuses: employed in manufacturing, employed in the public sector, other private employment, unemployed, or not in the labor force. The middle panel details the outcomes for people without a college education, and the lower panel shows the results for the group with a college education. Once again, we report the results for the regressions for total imports from China, where we remove the three largest cities and the 10 small fishing communities from the sample. First, we note that the negative effect of imports on manufacturing employment only holds for workers without a college education. Further, we find that exposure to imports from China increases unemployment and makes workers leave the labor force, but this effect also applies only to workers with less education. For workers without a college education, an increase in import exposure of 10,000 NOK per worker reduces manufacturing employment by about $0.8 \%$, while it increases employment in other private sectors by $0.5 \%$, unemployment by $1.8 \%$, and the number of people outside the labor force by $0.3 \%$. With the very generous welfare state in place in Norway in terms of disability pensions and unemployment benefits, we would expect the displacement of workers to increase both the number of unemployed people and the number of people leaving the labor force ${ }^{25}$

When it comes to wage effects, Table 9 presents the results of regressions where the dependent variable is the change in regional average earnings. In contrast to the results for the US from ADH, we do not find any effect on wages in Norway. This finding is also in accordance with existing results regarding job displacement in Norway (Huttunen et al., 2011), while for the US, strong and persistent negative wage effects are found for displaced workers (von Wachter and Bender, 2006).

\footnotetext{
${ }^{25}$ This is in line with previous findings on displacement for Norway. See Huttunen, Møen and Salvanes (2011).
} 


\section{Conclusion}

This paper analyzed to what extent the emergence of China as the world's largest manufacturing exporter has effected regional labor markets in Norway. From 1996 to 2007, Norwegian imports of products from China increased more than sixfold, but different labor market regions can have different exposures to the increase in import competition from China because of differences in regional industry structure. Regions with a large share of national employment in the production of goods that saw significant growth in imports from China had greater exposure to competition from China than other regions. We analyzed whether regional exposure to import competition from China affects manufacturing employment, and assessed to what extent the increased exposure to competition from China can explain the decrease in the manufacturing sector's employment share in Norway over the period from 1996 to 2007. We further analyzed how the negative effect of import exposure on manufacturing employment in turn affects labor mobility between regions and sectors, and other labor market outcomes, such as wages and unemployment.

To account for the possible simultaneity of import demand and labor demand shocks, we devised an instrument to capture Norwegian import growth from China by using the increase in similar imports from China to other developed countries. This instrumental variable strategy, developed by Autor et al. (2013), rests on the assumption that the Chinese supply shock has created similar bundles of exports from China to other developed countries, and that the increase in imports from China to other developed countries is uncorrelated with any labor demand shocks in Norwegian regions. We found a negative impact of regional exposure to competition from China on the manufacturing employment share in local labor markets. Further, this effect stemmed mostly from the import of intermediate goods rather than final goods, and from exposure to imports from China to Norway rather than competition with China in common export markets. Our estimates suggested that almost $10 \%$ of the reduction in the manufacturing employment 
share from 1996 to 2007 can be explained by increased import competition from China. This is about half of the magnitude found by Autor et al. (2013) for the US.

The reduction in manufacturing employment that we found for Norway because of the Chinese import shock primarily affects workers without a college degree, who find themselves partly pushed into unemployment, partly out of the labor force, and partly into employment in other private sectors. Despite differences between the US and Norway in terms of manufacturing structure, openness to trade, and labor market institutions, manufacturing employment in both countries has been negatively affected by the Chinese export supply shock since the early 1990s, although to a much smaller degree in Norway than in the US. In contrast to the findings for the US, we did not find any negative wage effects. These latter results are to be expected in a Nordic welfare state where wage flexibility is low, and thus where we instead expect the margin of adjustment to be on employment. 


\section{Tables}

Table 1: Regional differences in manufacturing employment shares

\begin{tabular}{|c|c|c|c|c|c|c|c|}
\hline \multicolumn{4}{|c|}{ Shares in 1996} & \multicolumn{4}{|c|}{ Change in shares 1996-2007 } \\
\hline \multicolumn{2}{|l|}{ Lowest share } & \multicolumn{2}{|c|}{ Highest share } & \multicolumn{2}{|c|}{ Largest increase } & \multicolumn{2}{|c|}{ Largest decrease } \\
\hline Namsskogan & 1.1 & Bremanger & 22.3 & Oppdal & 3.2 & Flora & 6.3 \\
\hline Hamarøy & 1.2 & Sunndal & 22.9 & Solund & 3.2 & Mås $\varnothing y$ & 8.1 \\
\hline Leka & 1.3 & Årdal & 24.3 & Flatanger & 3.5 & Utsira & 9.1 \\
\hline Rørvik & 1.4 & Stranda & 24.7 & Fyresdal & 3.7 & Fedje & 10.1 \\
\hline Porsanger & 1.9 & Høyanger & 24.7 & Træna & 4.9 & Båtsfjord & 12.3 \\
\hline Aurland & 2.2 & Båtsfjord & 27.5 & Sand $\varnothing y$ & 4.9 & Vard $\varnothing$ & 14.7 \\
\hline \multicolumn{4}{|c|}{ Average share in 1996: $9.9 \%$} & \multicolumn{4}{|c|}{ Average change: $-1.9 \%$} \\
\hline
\end{tabular}

Table 2: Change in imports from China 1996-2007: 1000 NOK per worker

\begin{tabular}{|c|c|c|c|c|c|c|c|}
\hline \multicolumn{4}{|c|}{ Imports of intermediates } & \multicolumn{4}{|c|}{ Imports of final goods } \\
\hline \multicolumn{2}{|c|}{ Least exposed } & \multicolumn{2}{|c|}{ Most exposed } & \multicolumn{2}{|c|}{ Least exposed } & \multicolumn{2}{|l|}{ Most exposed } \\
\hline Gamvik & 0 & Bremanger & 39 & Bindal & 0 & Beiarn & 46 \\
\hline Leka & 0 & Fredrikstad & 34 & Hattfjelldal & 0 & Stranda & 67 \\
\hline Modalen & 0 & Grenland & 28 & Leka & 0 & Ørsta-Volda & 42 \\
\hline Moskenes & 0 & Moss & 92 & Modalen & 0 & Rauma & 46 \\
\hline $\mathrm{R} \varnothing \mathrm{d} \varnothing \mathrm{y}$ & 0 & Risør & 44 & Røyrvik & 0 & Stryn & 66 \\
\hline Solund & 0 & Sandefjord & 38 & Vik & 0 & Tydal & 46 \\
\hline \multicolumn{4}{|c|}{ Average change: $7.7 \mathrm{NOK}$} & \multicolumn{4}{|c|}{ Average change: $6.1 \mathrm{NOK}$} \\
\hline
\end{tabular}


Table 3: Change in trade exposure 1996-2007: 1000 NOK per worker

\begin{tabular}{lrrrrr}
\hline & $\min$ & $\mathrm{p} 25$ & $\mathrm{p} 50$ & $\mathrm{p} 75$ & $\max$ \\
\hline Exposure through total imports from China & 0 & 1 & 4 & 12 & 112 \\
Exposure to China in export markets & 0 & 0 & 0 & 0 & 24 \\
Exposure in both imp. and exp. market & 0 & 1 & 4 & 12 & 112 \\
Change in exports to China & 0 & 0 & 2 & 6 & 44 \\
Net import and export m. exposure & -40 & -1 & 2 & 10 & 101 \\
Change in other exports & -10 & 9 & 32 & 79 & 1099 \\
\hline
\end{tabular}

Table 4: Change in manufacturing employment share and imports from China, OLS estimates

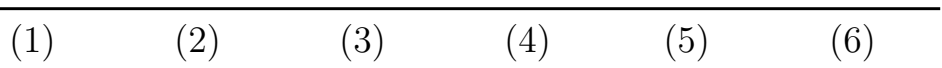

\begin{tabular}{lcccccc}
\hline \multicolumn{1}{c}{ Domestic exposure to China: } & & & & & \\
Total imports & $-0.144^{* *}$ & $-0.137^{* *}$ & $-0.147^{* *}$ & & & \\
& $(0.057)$ & $(0.056)$ & $(0.059)$ & & & \\
Intermediates & & & & $-0.214^{* *}$ & & $-0.218^{* * *}$ \\
& & & & $(0.076)$ & & $(0.066)$ \\
Final goods & & & & & -0.144 & 0.017 \\
& & & & & $(0.145)$ & $(0.090)$ \\
Controls: & & & & & & \\
Manuf Empl/Pop & -0.032 & $-0.070^{*}$ & $-0.078^{*}$ & $-0.079^{*}$ & $-0.083^{*}$ & $-0.079^{*}$ \\
& $(0.023)$ & $(0.037)$ & $(0.040)$ & $(0.040)$ & $(0.040)$ & $(0.041)$ \\
College/Pop & & -0.027 & -0.027 & -0.027 & -0.024 & -0.026 \\
& & $(0.019)$ & $(0.019)$ & $(0.020)$ & $(0.019)$ & $(0.019)$ \\
$\Delta$ Export & & & $0.011^{*}$ & $0.013^{* *}$ & 0.008 & $0.014^{*}$ \\
& & & $(0.006)$ & $(0.006)$ & $(0.010)$ & $(0.007)$ \\
Region dummies & No & Yes & Yes & Yes & Yes & Yes \\
Period dummy & No & Yes & Yes & Yes & Yes & Yes \\
\hline Observations & 320 & 320 & 320 & 320 & 320 & 320 \\
$R^{2}$ & 0.079 & 0.160 & 0.164 & 0.170 & 0.139 & 0.168 \\
\hline
\end{tabular}

Dependent var. is \% pts change in the share of working-age population employed in manufacturing. Each regression contains two observations per region, each weighted with start of period population. Standard errors in parentheses are clustered by county. ${ }^{*} p<0.10,{ }^{* *} p<0.05,{ }^{* * *} p<0.01$. 
Table 5: Change in manufacturing employment share and different measures of change in exposure to competition from China, 2SLS estimates

\begin{tabular}{|c|c|c|c|}
\hline $\begin{array}{l}\text { Domestic } \\
\text { exposure }\end{array}$ & $\begin{array}{l}\text { Net domestic } \\
\text { exposure }\end{array}$ & $\begin{array}{l}\text { Domestic }+ \\
\text { intl exposure }\end{array}$ & $\begin{array}{l}\text { Net domestic }+ \\
\text { intl exposure }\end{array}$ \\
\hline$(1)$ & $(2)$ & (3) & $(4)$ \\
\hline \multicolumn{4}{|c|}{ Panel A: Full sample with $N=320$} \\
\hline $\begin{array}{c}-0.139^{* * *} \\
(0.039)\end{array}$ & $\begin{array}{c}-0.152^{* * *} \\
(0.044)\end{array}$ & $\begin{array}{c}-0.139^{* * *} \\
(0.039)\end{array}$ & $\begin{array}{c}-0.152^{* * *} \\
(0.044)\end{array}$ \\
\hline \multicolumn{4}{|c|}{ Panel B: Dropping 10 fish-processing regions $N=300$} \\
\hline $\begin{array}{c}-0.139^{* * *} \\
(0.042)\end{array}$ & $\begin{array}{c}-0.151^{* * *} \\
(0.046)\end{array}$ & $\begin{array}{c}-0.140^{* * *} \\
(0.042)\end{array}$ & $\begin{array}{c}-0.152^{* * *} \\
(0.046)\end{array}$ \\
\hline \multicolumn{4}{|c|}{ Panel C: Dropping from panel $B$ the three largest cities $N=294$} \\
\hline $\begin{array}{c}-0.125^{* *} \\
(0.041)\end{array}$ & $\begin{array}{c}-0.136^{* *} \\
(0.045)\end{array}$ & $\begin{array}{c}-0.126^{* *} \\
(0.041)\end{array}$ & $\begin{array}{c}-0.137^{* *} \\
(0.045)\end{array}$ \\
\hline
\end{tabular}

Dependent var. is \% pts change in the share of working-age population employed in manufacturing. Each regression contains two observations per region, each weighted with start of period population, and contains the same control variables as column 3 of table 3 .

Standard errors in parentheses are clustered by county. ${ }^{*} p<0.10,{ }^{* *} p<0.05,{ }^{* * *} p<0.01$. 
Table 6: Change in manufacturing employment share and imports from China, 2SLS estimates for different periods

\begin{tabular}{|c|c|c|c|c|}
\hline & $\begin{array}{l}\text { 1996-2007 } \\
\text { Stacked } \\
\end{array}$ & $\begin{array}{l}\text { 1996-2007 } \\
\text { Long }\end{array}$ & 1996-2001 & 2002-2007 \\
\hline & (1) & $(2)$ & (3) & (4) \\
\hline $\begin{array}{l}\Delta \text { Domestic exposure } \\
\text { to China: }\end{array}$ & $\begin{array}{c}-0.125^{* * *} \\
(0.041)\end{array}$ & $\begin{array}{l}-0.071 \\
(0.046)\end{array}$ & $\begin{array}{l}0.078 \\
(0.571)\end{array}$ & $\begin{array}{c}-0.126^{* * *} \\
(0.046)\end{array}$ \\
\hline Controls & Yes & Yes & Yes & Yes \\
\hline Region dummies & Yes & Yes & Yes & Yes \\
\hline Period dummy & Yes & No & No & No \\
\hline Observations & 294 & 147 & 147 & 147 \\
\hline$R^{2}$ & 0.166 & 0.354 & 0.127 & 0.277 \\
\hline
\end{tabular}

Dependent var. is \% pts change in the share of working-age population employed in manufacturing.

Each regression contains the same control variables as column 3 of table 3 .

Standard errors in parentheses are clustered by county. ${ }^{*} p<0.10,{ }^{* *} p<0.05,{ }^{* * *} p<0.01$.

Table 7: Mobility response: Change in population and imports from China, 2SLS estimates

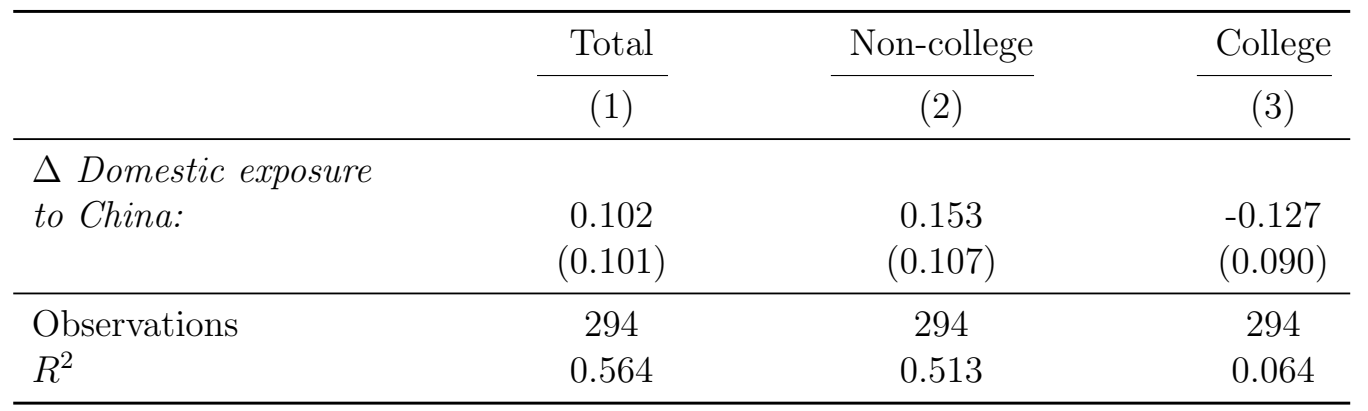

Dependent var. is $100 \times \log$ change in head counts of group indicated in column heading.

Each regression contains the same control variables as column 3 of table 3 .

Standard errors in parentheses are clustered by county. ${ }^{*} p<0.10,{ }^{* *} p<0.05,{ }^{* * *} p<0.01$. 
Table 8: Labor market response: Change in labor market status and imports from China, 2SLS estimates

\begin{tabular}{|c|c|c|c|c|c|}
\hline & Manufacturing & Public Empl & Other & Unemployed & Outside \\
\hline & $(1)$ & $(2)$ & $(3)$ & $(4)$ & $(5)$ \\
\hline & \multicolumn{5}{|c|}{ All workers } \\
\hline \multirow[t]{2}{*}{$\Delta$ Dom exp to China } & $-0.779^{*}$ & 0.094 & $0.460^{* * *}$ & $1.592^{*}$ & 0.125 \\
\hline & $(0.447)$ & $(0.228)$ & $(0.165)$ & $(0.939)$ & $(0.173)$ \\
\hline \multirow{3}{*}{$\begin{array}{l}\text { Observations } \\
R^{2}\end{array}$} & 293 & 294 & 294 & 294 & 294 \\
\hline & 0.113 & 0.164 & 0.252 & 0.079 & 0.431 \\
\hline & \multicolumn{5}{|c|}{ Non-college educated } \\
\hline \multirow[t]{2}{*}{$\Delta$ Dom exp to China } & $-0.768^{*}$ & -0.242 & $0.498^{* * *}$ & $1.846^{*}$ & $0.291^{*}$ \\
\hline & $(0.454)$ & $(0.338)$ & $(0.176)$ & (1.017) & $(0.166)$ \\
\hline Observations & 293 & 294 & 294 & 294 & 294 \\
\hline & 0.089 & 0.132 & 0.254 & 0.053 & 0.385 \\
\hline & \multicolumn{5}{|c|}{ College educated } \\
\hline \multirow[t]{2}{*}{$\Delta$ Dom exp to China } & -0.547 & $0.337^{* * *}$ & 0.153 & -1.162 & $-1.011^{* *}$ \\
\hline & $(0.803)$ & $(0.095)$ & $(0.202)$ & $(1.175)$ & $(0.396)$ \\
\hline Observations & 273 & 294 & 294 & 271 & 294 \\
\hline$R^{2}$ & 0.062 & 0.028 & 0.071 & 0.205 & 0.072 \\
\hline
\end{tabular}

Dependent var. is $100 \times \log$ change in head counts of group indicated in column heading.

Each regression contains the same control variables as column 3 of table 3 .

Standard errors in parentheses are clustered by county. ${ }^{*} p<0.10,{ }^{* *} p<0.05,{ }^{* * *} p<0.01$. 
Table 9: Wage response: Change in log earnings and imports from China, 2SLS estimates

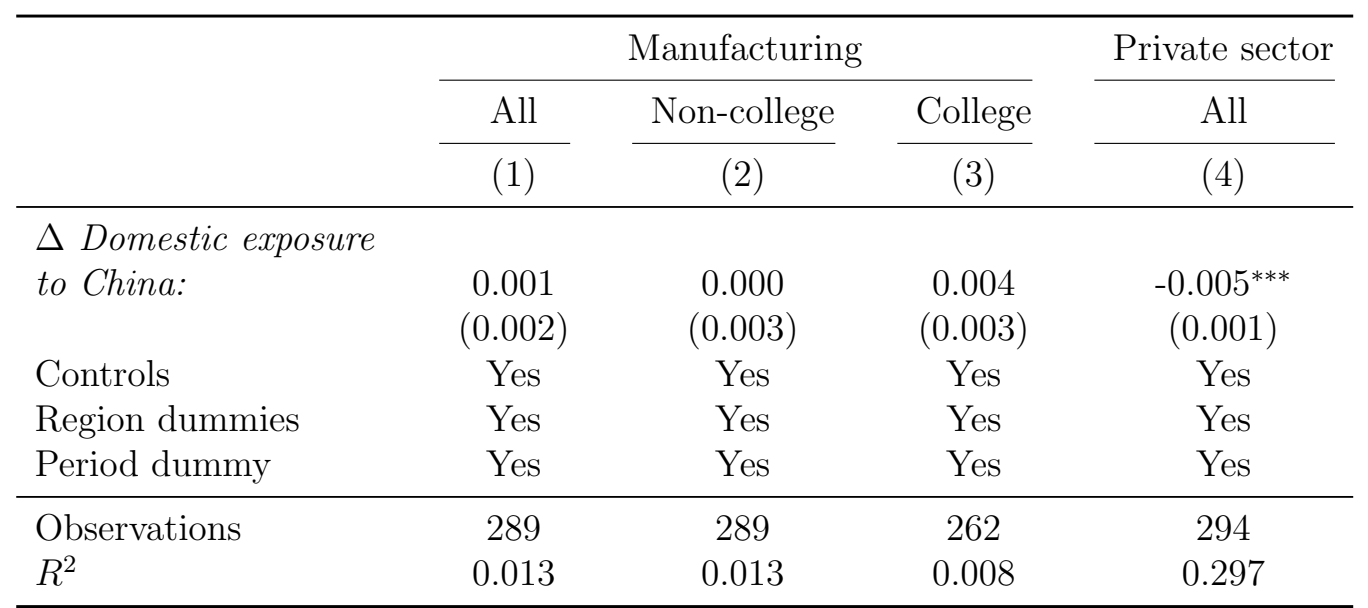

Dependent var. is change in log earnings of group indicated in column heading.

Each regression contains the same control variables as column 3 of table 3 .

Standard errors in parentheses are clustered by county. ${ }^{*} p<0.10,{ }^{* *} p<0.05,{ }^{* * *} p<0.01$. 


\section{Figures}

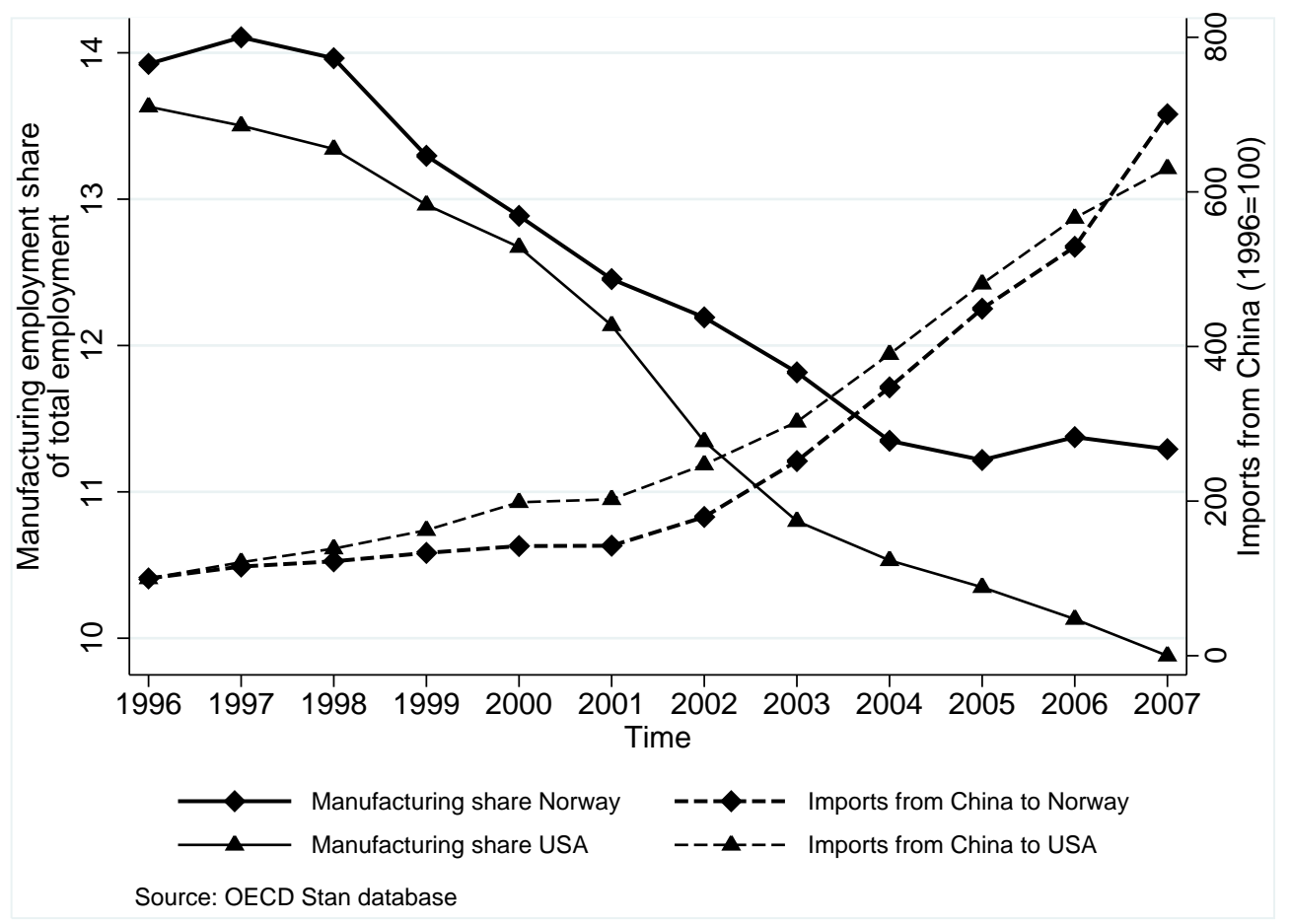

Figure 1: Manufacturing employment shares and imports from China 


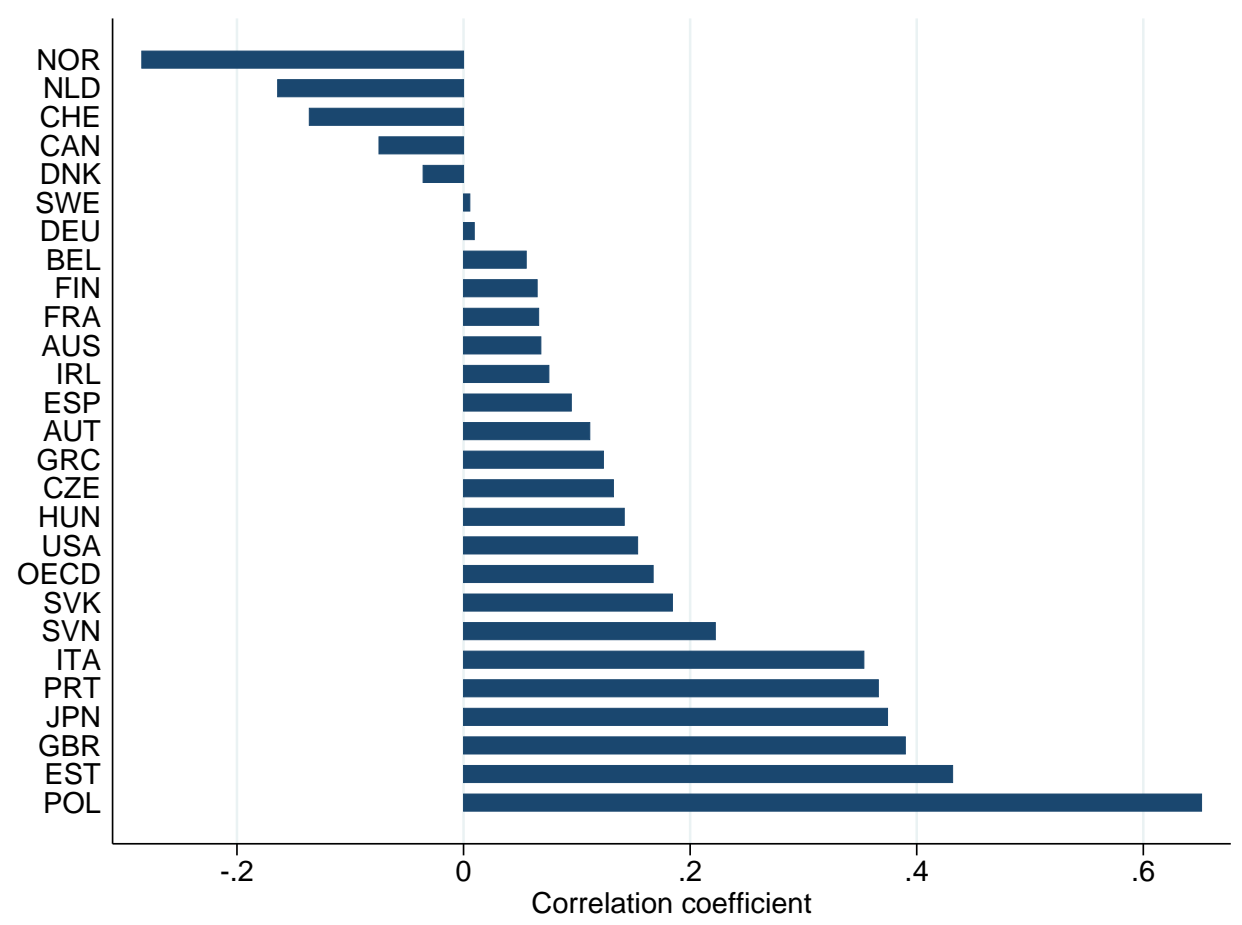

Source: OECD STAN Bilateral Trade Database and STAN Indicators

Figure 2: Correlation between industry employment shares in 1996 and the change in total Chinese exports in 1996-2007 for 20 manufacturing industries 


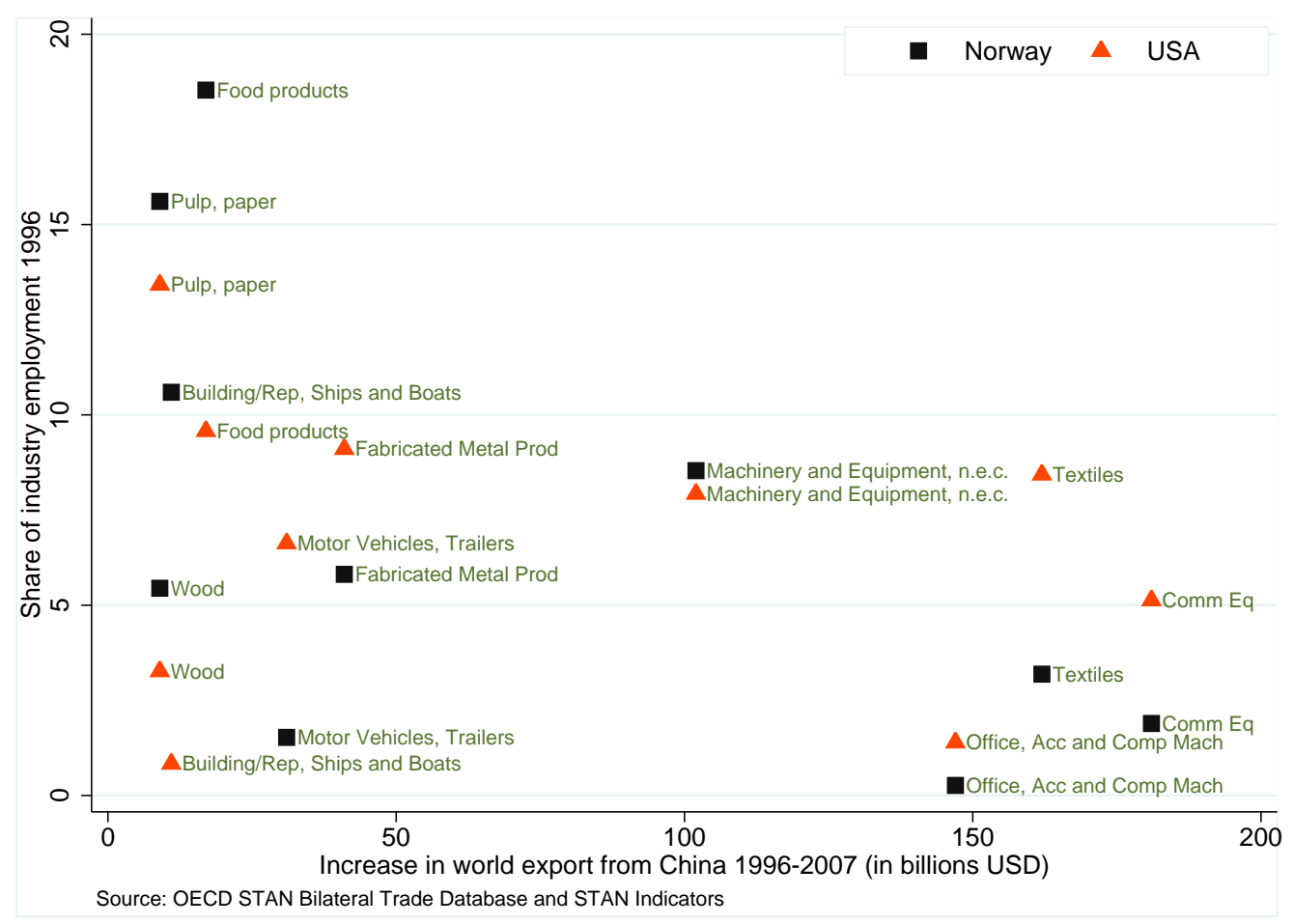

Figure 3: Differences in industry structure between Norway and the US 


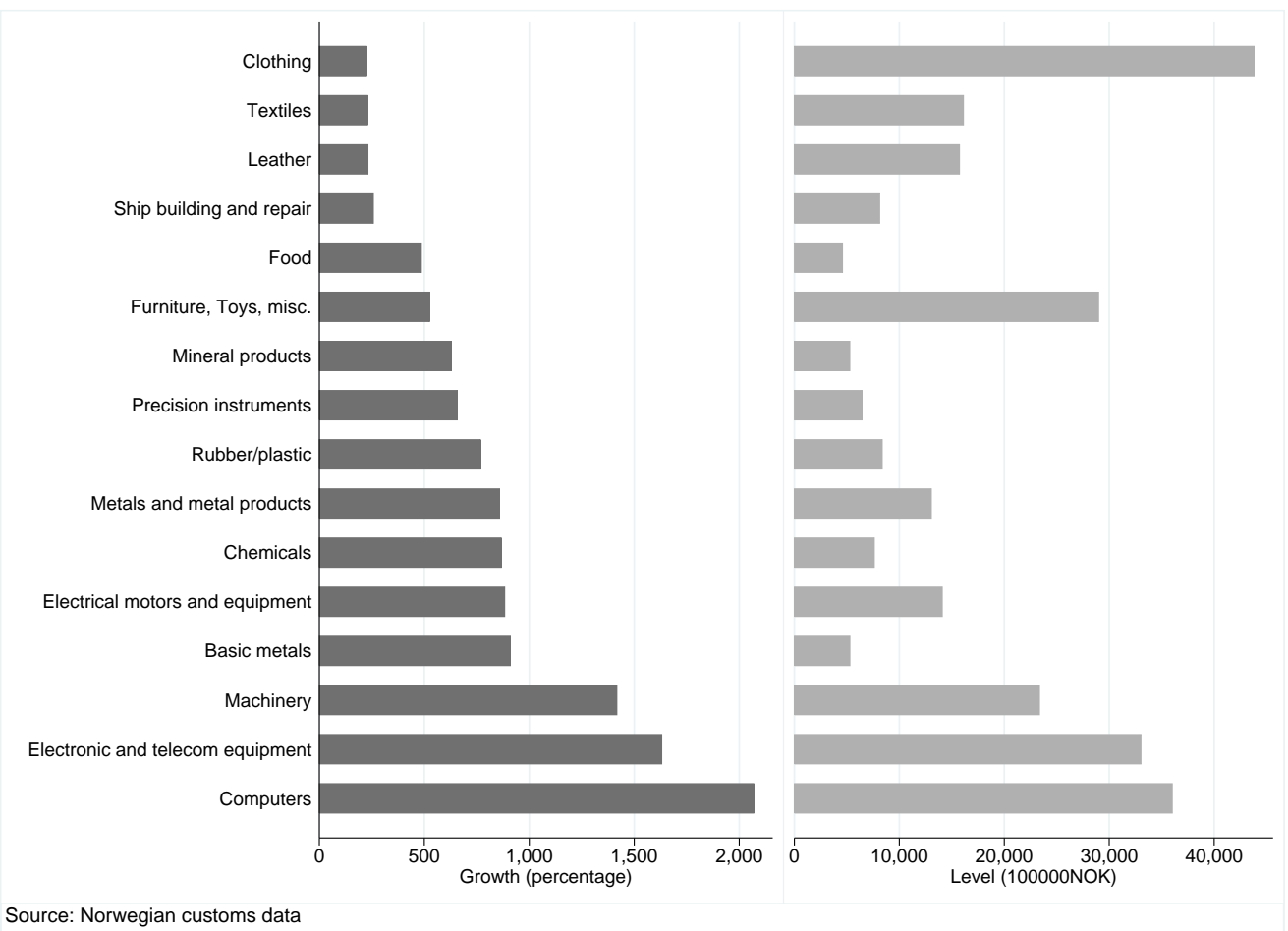

Figure 4: Imports from China by producing industry 


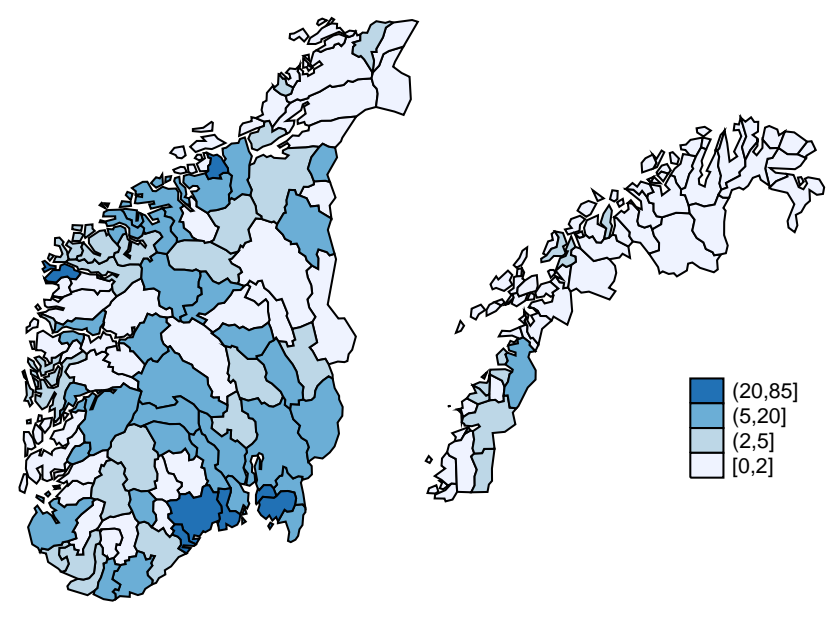

(a) Imports of intermediate goods

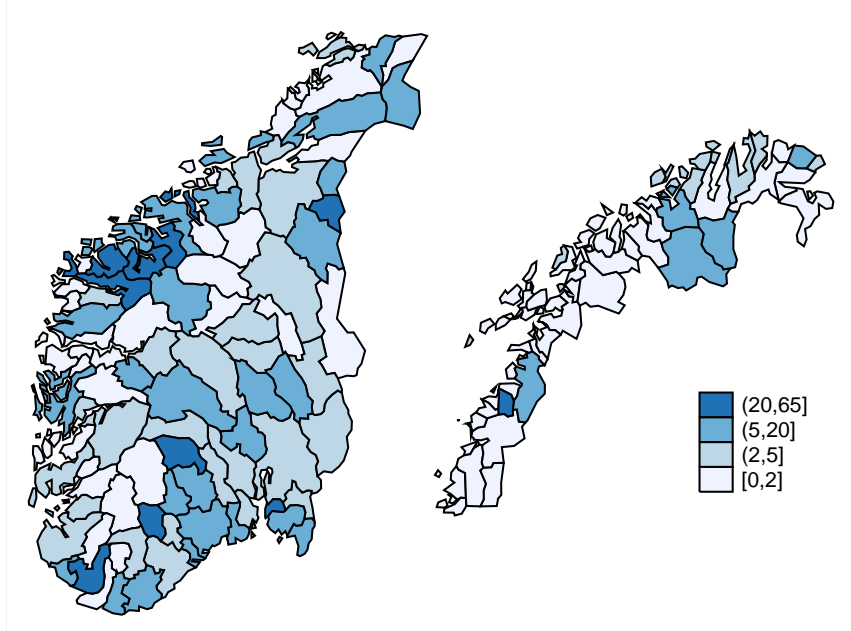

(b) Imports of final goods

Figure 5: Change in regional exposure to imports from China: 1,000 NOK per worker 


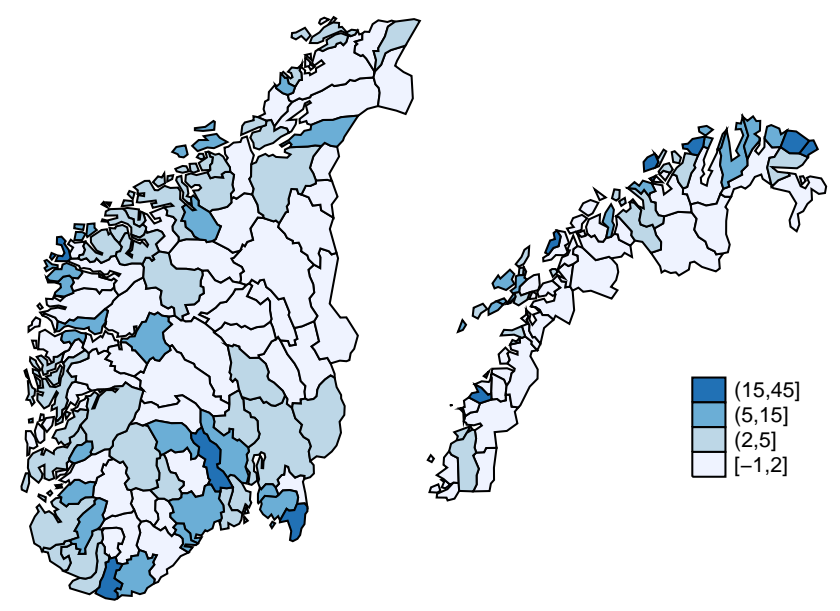

(a) Exports to China

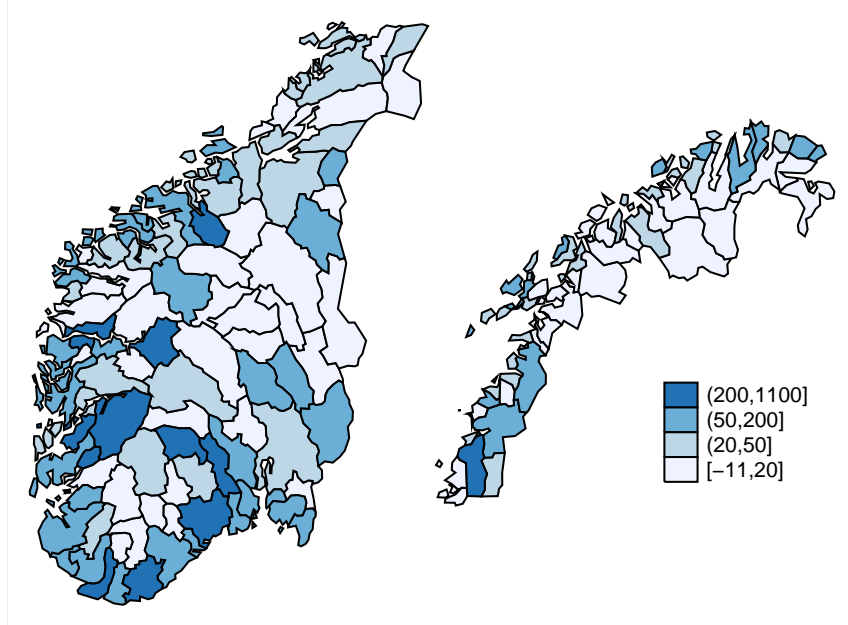

(b) Total exports, not to China

Figure 6: Change in regional exports: 1,000 NOK per worker 


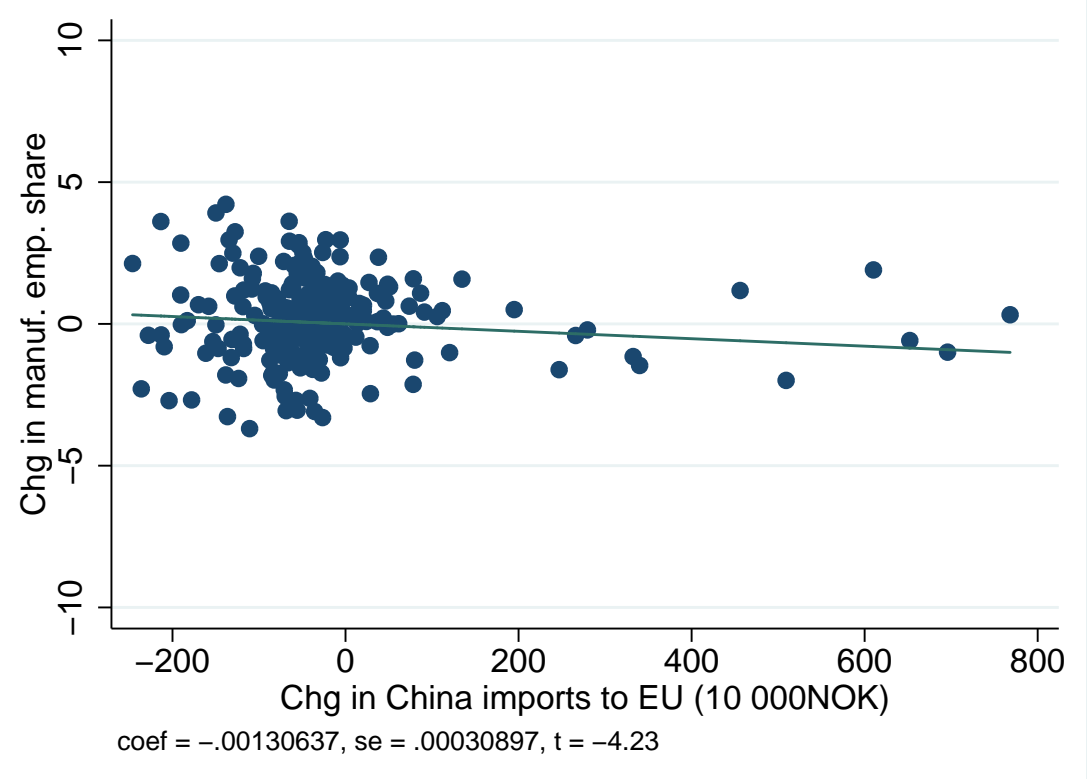

(a) OLS reduced form

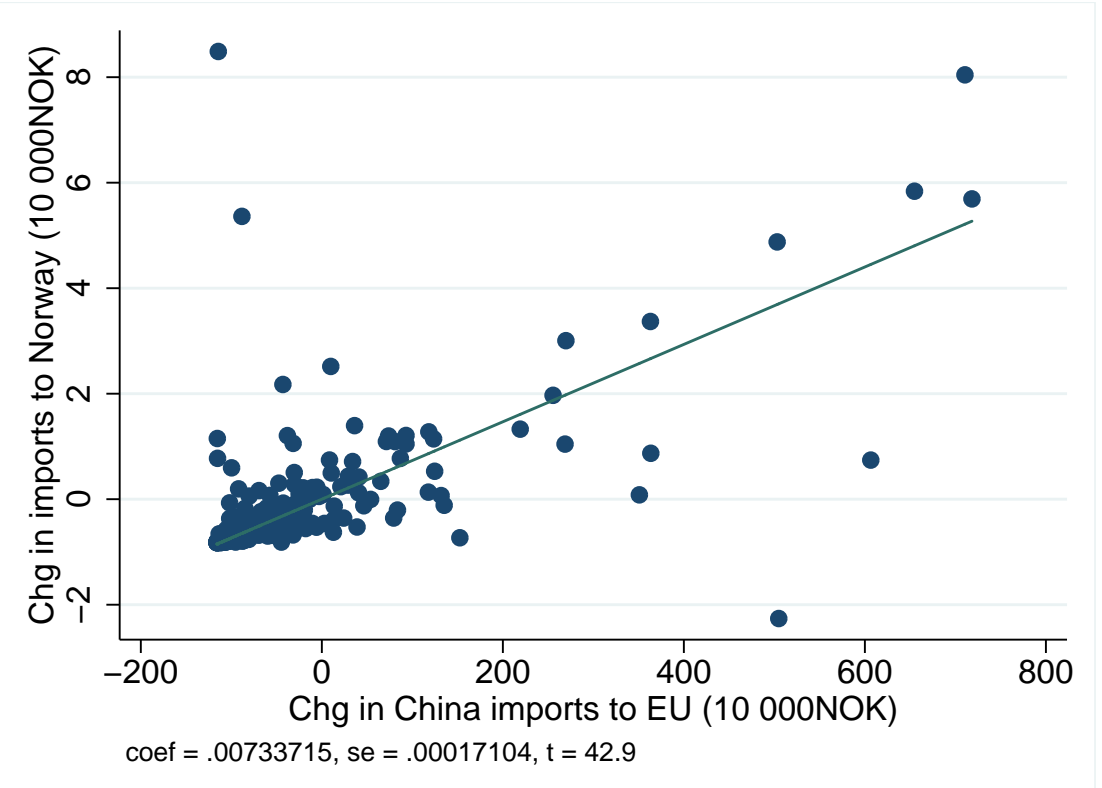

(b) First stage regression

Figure 7: Manufacturing employment shares and imports from China: Reduced form and first stage for 1996-2007 


\section{References}

Aaberge, R., A. Bjorklund and N. Smith (2000). "Unemployment shocks and income distribution: How did the Nordic countries fare during their crises?" Scandinavian Journal of Economics, 102(1), 77-99. 4

Agell, J. and K. E. Lommerud (1997). "Minimum wages and the incentives for skill formation." Journal of Public Economics, 64(1), 25-40. 4

Amiti, M. and D. R. Davis (2012). "Trade, firms, and wages: Theory and evidence." Review of Economic Studies, 79(1), 1-36. 3

Arkolakis, C., A. Costinot and A. Rodriguez-Clare (2012). "New trade models, same old gains?" American Economic Review, 102(1), 94-130. 9

Autor, D. H., D. Dorn and G. H. Hanson (2013). "The China syndrome: Local labor market effects of import competition in the United States." American Economic Review, 103, 2121-68. 1, 2, 3, 5, 26, 27

Berman, E., J. Bound and S. Machin (1998). "Implications of skill-biased technological change: International evidence." The Quarterly Journal of Economics, 113(4), 1245-1279. 2

Bernard, A. B., J. B. Jensen and P. K. Schott (2006). "Survival of the best fit: Exposure to low-wage countries and the (uneven) growth of US manufacturing plants." Journal of International Economics, 68(1), 219 237. 3

Beveren, I. V., A. B. Bernard and H. Vandenbussche (2012). "Concording EU trade and production data over time." NBER Working Paper Series 18604. 15

Bloom, N., M. Draca and J. V. Reenen (2011). "Trade induced technical change? The impact of Chinese imports on innovation, IT and productivity." Working Paper 16717, National Bureau of Economic Research. 9 
Chiquiar, D. (2008). "Globalization, regional wage differentials and the Stolper-Samuelson theorem: Evidence from Mexico." Journal of International Economics, 74(1), 70 - 93. 3

Dauth, W., S. Findeisen and J. Suedekum (2014). "The rise of the east and the far east: German labor markets and trade integration." Journal of the European Economic Association, forthcoming. 6

Donoso, V., V. Martín and A. Minondo (2014). "Do differences in the exposure to Chinese imports lead to differences in local labour market outcomes? An analysis for Spanish provinces." Regional Studies, pp. 1-19. 5

Ebenstein, A., A. Harrison, M. McMillan and S. Phillips (2011). "Estimating the impact of trade and offshoring on American workers using the current population surveys." The World Bank, Policy Research Working Paper Series: 5750. 3

Gundersen, F. and D. Jukvam (2013). "Inndelinger i senterstruktur, sentralitet og ba regioner." NIBR-rapport 2013-1. 15

Hægeland, T., T. J. Klette and K. G. Salvanes (1999). "Declining returns to education in norway? Comparing estimates across cohorts, sectors and over time." Scandinavian Journal of Economics, 101(4), 555-576. 4

Helpman, E. and P. Krugman (1985). Market structure and foreign trade. MIT Press, Cambridge, Mass. 9

Hummels, D., R. Jorgensen, J. Munch and C. Xiang (2014). "The wage effects of offshoring: Evidence from Danish matched worker-firm data." American Economic Review, forthcoming. 3

Huttunen, K., J. Møen and K. G. Salvanes (2011). "How destructive is creative destruction? Effects of job loss on mobility, withdrawal and income." Journal of the European Economic Association, 9(4), 840-870. 25

Kahn, L. (1998). "Against the wind: Bargaining recentralisation and wage inequality in Norway 1987-91." The Economic Journal, 108, 603-645. 4 
Kovak, B. K. (2013). "Regional effects of trade reform: What is the correct measure of liberalization?" American Economic Review, 103, 1960-1976. 3

Krugman, P. R. (2008). "Trade and wages, reconsidered." Brookings Papers on Economic Activity, 39(1), 103-154. 2

Moene, K. O. and M. Wallerstein (1997). "Pay inequality." Journal of Labor Economics, 15(3), 403-30. 4

Salvanes, K. G. and S. E. Førre (2004). "Effects on employment of trade and technical change: Evidence from Norway." Economica, 70, 293-329. 2

Topalova, P. (2010). "Factor immobility and regional impacts of trade liberalization: Evidence on poverty from India." American Economic Journal: Applied Economics, 2(4), 1 - 41. 3

Verhoogen, E. A. (2008). "Trade, quality upgrading, and wage inequality in the Mexican manufacturing sector." Quarterly Journal of Economics, 123(2), 489 - 530. 3

von Wachter, T. and S. Bender (2006). "In the right place at the wrong time: The role of firms and luck in young workers' careers." The American Economic Review, 96(5), 1679-1705. 25 


\section{A Appendix}

Table A.1: First stage

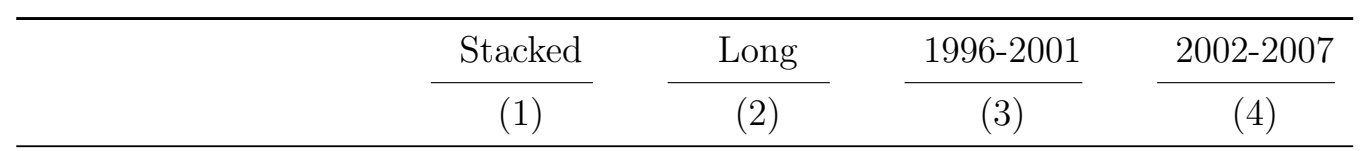

$\Delta$ Domestic exposure to Chinese Import/Worker, of

$\begin{array}{lcccc}\text { Total trade } & 0.0072^{* * *} & 0.0061^{* * *} & 0.0029^{* * *} & 0.0077^{* * *} \\ & (0.0005) & (0.0004) & (0.0004) & (0.0003) \\ \text { Intermediate goods } & 0.0063^{* * *} & 0.0050^{* * *} & 0.0022^{* * *} & 0.0064^{* * *} \\ & (0.0004) & (0.0004) & (0.0002) & (0.0003) \\ \text { Finished goods } & 0.0066^{* * *} & 0.0081^{* * *} & 0.0031^{* * *} & 0.0091^{* * *} \\ & (0.0013) & (0.0009) & (0.0010) & (0.0006)\end{array}$

$\Delta$ Net domestic exposure to Chinese Import/Worker, of

\begin{tabular}{|c|c|c|}
\hline trade & $\begin{array}{c}0.0066^{* *} \\
(0.0004)\end{array}$ & $\begin{array}{c}0.0056^{* * *} \\
(0.0005)\end{array}$ \\
\hline
\end{tabular}

$\Delta$ Domestic + Intn'l exposure to Chinese Import/Worker, of

\begin{tabular}{|c|c|c|}
\hline de & $\begin{array}{c}0.0072^{* *} \\
(0.0005\end{array}$ & $\begin{array}{c}0.0060^{* *} \\
(0.0004\end{array}$ \\
\hline
\end{tabular}

$\Delta$ Net Domestic + Intn'l exposure to Chinese Import/Worker, of

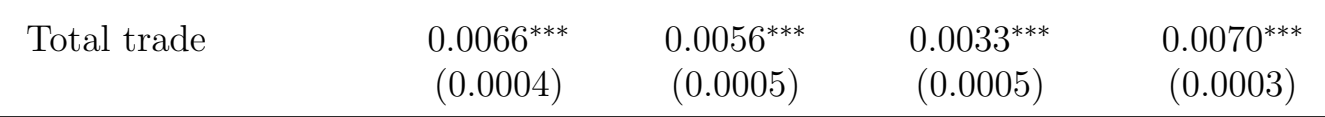

Standard errors, in parenthesis, are clustered by county. ${ }^{*} p<0.10,{ }^{* *} p<0.05,{ }^{* * *} p<0.01$

Controls: Start of period values of manufacturing employment share, start of period college

share of working age populations, change in regions total export except China.

Region and time period dummies in all columns. 